\title{
Analysis and modeling of the relationship "maintenance-environment" Case study of an SME in the agri-food sector
}

\author{
Halima TAJRI $^{\# 1}$, Mohammed EL HAMMOUMI ${ }^{* 2}$, Brahim HERROU ${ }^{\# 3}$ \\ \# Laboratory of Industrial Technologies (LTI), Faculty of Science and Technology FST, \\ University Sidi Mohammed ben Abdallah, Fez, Morocco. \\ ${ }^{1}$ halimatajri@gmail.com \\ 2m_elhammoumi@yahoo.fr \\ ${ }^{3}$ herroubrahim @yahoo.fr
}

\begin{abstract}
The Companies are evolving today in an economic context marked by competition increasingly fierce and more demanding customers. To differentiate from the mass, nothing is worth an environmental certification. Moroccan companies have finally understood and are thus more likely to take the plunge.

The challenges of competitiveness, profitability and environmental protection issues call on the maintenance function and make it one of the pillars of the environmental management system.

In this paper, we analyze the relation « environment-maintenance " and we present the model resulting from this analysis. This model allows illustrating the impact of the maintenance on the environment performance improvement, then, the effects of the environment management on the maintenance.
\end{abstract}

Also, we present in this paper the industrial application for experimenting our model in the framework of a Moroccan company in the agri-food sector. The collected and observed results have confirmed the assumptions expressed by our model.

\section{INTRODUCTION}

Nowadays, more and more companies are communicating about their commitments to protect the environment through advertising campaigns, sustainable development reports, the display of environmental certification and labels, and so on. For the latter, the implementation of an Environmental Management System (EMS) has also become an imperative for regulatory compliance (environmental law), a response to the concerns of shareholders and consumers, a condition of their sustainability and a non-negligible element of competitiveness, and therefore of the whole performance. Sustainable development, in particular, its environmental dimension has become a new strategic creation area, a source for improving the company's performance.

Thus, within the context of environmental management, there are two reasons for improving the technologies currently implemented in industries:

- Reduce the environmental aspects emissions.

- Reduce consumption of matter and energy

These two reasons strongly call for the maintenance function, which has become one of the strategic functions of the company. The company must lead an efficient maintenance strategy for its production means in order to improve their availability and reduce their environmental aspects.

In this paper, we first define the concepts related to the maintenance, the green maintenance and the Environmental Management System (EMS). Then, we analyze the impact of maintenance on the environment and the impact of the EMS on the maintenance and we deduce the global model on the "maintenanceenvironment" relationship. Finally, we try to validate our model in the company BOISGAZ.

\section{Definitions}

\section{A. Definition of the maintenance}

The definition and development of the maintenance concept has been addressed by numerous research studies (e.g. [1], [2], [3], [4], [5]). Also, the French standard gave several definitions of the maintenance function (see the definition of NF X 60-010 standard and AFNOR NF X 60-000 integrating the economic aspect). As part of our research, we use the definition of the standard NF EN 13306: maintenance is the set of all technical, administrative and management tasks during the life cycle of an asset, intended to maintain or restore it to a state in which it can perform a required function. This definition introduces the maintenance concept throughout the whole life cycle of a material; this was missing in that of standard NF X 60-010. 
Traditional definitions of maintenance focus on 'good functioning'. Admittedly, the concept of 'good functioning' can also include respect of the environment (functioning without any overconsumption of energy and matter, nor pollution of air, soil and water). But it is clear that this notion refers more to the availability of a machine and the environmental dimension remains implicit if not absent. Thus, the integration of the criterion 'respect of the environment' in the definition of maintenance would help to respect the environment. Indeed, the integration of the environmental dimension in the definition urges maintenance managers to calculate, optimize and integrate environmental costs into maintenance costs.

It is about the cost of penalties due to the environmental degradation provoked by the system. We cite in this regard the research work of [6] which proposed to optimize the maintenance costs by integrating the cost related to the environment.

Finally, the integration of the environmental dimension into maintenance shows, in our opinion, the concept of green maintenance. We have defined this concept as follows: "The set of all technical, administrative and management tasks during the life cycle of an asset, intended to maintain or restore it to a state in which it can perform a required function in an environmentally sound manner". It means a healthy maintenance that ensures operation with the least breakdowns and limits any generation of negative impact on the environment.

\section{B. Definition of the Environmental Management System (EMS)}

In the literature, several works have defined the EMS (see, for example, (EMAS), [7], [8], [9], [10). In the same sense, the international standard ISO 14001, the most widely accepted by companies [11], defines the EMS as the organization management system component used to develop and implement its environmental policy and manage its environmental aspects. A management system is a set of interrelated elements used to establish policy and objectives, also the means to achieve these objectives. It includes the organizational structure, planning activities, responsibilities, practices, procedures, processes and resources.

\section{Definition of the Environmental Management System Performance (EMSP)}

The performance has always been considered as an ambiguous concept. Many researchers have attempted to give it a holistic and precise definition ([12], [13], [14], [15], [16], etc.). Environmental performance is a concept that is largely vague, contingent, and a source of subjective interpretations [17]. It is briefly defined in ISO 14001 as the measurable results of environmental aspects management.

However, this definition is insufficient to accurately understand what Environmental Performance (EP) means.

Thus, it is defined to be the measurable results of the environmental management system (EMS), in relation to the organization's control of its environmental aspects on the basis of its environmental policy, its environmental objectives and targets (ISO 14031 Standard, 1999, p. 2). The performance depends on the environmental policy which is by definition unique; therefore, it is a contingent notion to each company. In fact, this policy takes into account the mission, sector, local and regional conditions specific to each company as well as the requirements of its stakeholders [18].

According to Dias-Sardinha, the environmental performance can have six objectives: the compliance with laws, prevention of pollution, eco-efficiency, eco-innovation, eco-ethics and sustainability [19].

The performance, in the Lebas point of view, exists only if there is the possibility of measuring it and this measurement is not limited to the knowledge of a result [15]. It is then necessary to evaluate the achieved results by comparing them to desired results, standard results or standards [20].

\section{Definition of performance measurement for the maintenance function}

The importance of the maintenance performance measuring has been widely discussed by many authors ([21],[22], [23], [24], [25]). Maintenance function managers need performance information in order to monitor and control maintenance processes and their results, and to provide thereafter an indication of improvement.

Due to the maintenance role changing and the increasing complexity of manufacturing technologies, maintenance costs have evolved [26]. In industry, maintenance costs are estimated at $25 \%$ of the total operating cost ([27], [28]). In some industries, such as petrochemicals, electric power and mining, maintenance costs may exceed operating costs ([29], [30], [31], [26]). As such, particular attention should be paid to maintenance performance measurement, in order to use the limited maintenance resources more efficiently and to improve the overall organization efficiency.

The maintenance performance management system shall be designed to monitor and improve the various aspects of the maintenance effort. This process must be guided by the integration of the critical success factors of the enterprise, which are derived from the overall organization strategy.

The development of maintenance performance measurement tools is based on three concepts that define three main orientations:

- The cost,

- $\quad$ The reliability \& maintainability and 
- $\quad$ The availability ([32], [33], [34]).

Several works were conducted to define measurement and monitoring tools (ratios and indicators) for the performance of the maintenance function. Examples include the work of the French Association of Governing Councils (FAGC), the work of the "Center for Interfirm Comparison" and the work of Luis Janssens, who has developed specific indicators for cement plants and similar industries [34].

In the same vein, we note the works on the optimization ratios of total cost [35] and the TPM ratios [36].

The AFNOR X60-020 standard presents also indicators of maintenance cost, availability, security level and cost of failure, whereas the work of [37] proposes an approach to performance evaluation of the production systems integrating the direct effects of maintenance activities and it is based on the definition of indicators suitable for production and maintenance.

Finally, we cite the research work of [38] which proposed a method of generating maintenance indicators based on a semi-parametric approach and a Markov approach.

This presented bibliography shows that it is not possible to offer standard indicators that can be valid for any company, whatever its activity, its objectives and orientations, the level of understanding, training and involvement of its staff. Each maintenance department must find its appropriate indicators. The choice of the indicator depends on the use of the information that one wants to make, and belongs to each person in charge. It should make it possible to monitor and verify the functioning of the process and the achievement of the objectives [39].

\section{Analysis and modeling of the relationship " maintenance - environment "}

Research studies analyzing the impacts of a system (e.g. process, machine, etc.) on the environment or dealing with the relationship between environment and business are numerous (see, for example, [40], [41], [42], [43], [44] [45], [46], etc.). However, few works deal with the relationship between maintenance and environment, so this relationship remains implicit in a context where the protection of the environment is a major stake.

On the other hand, the production systems that constitute an important part of the capital of most industries are subject to the degradation related to the age and the use of such systems. This degradation affects not only the quality of the product, but also that of the environment. In fact, the industrial systems degradation can have significant impacts on the environment.

To meet the requirements of environmental standards and regulations, companies and in particular their maintenance departments must develop and implement innovative methods and strategies that allows to improve their performance for one hand, and to rationally exploit the available hardware resources on the other hand. This exploitation must be performed taking into account the impacts of industrial systems on the environment.

Perusing the literature on maintenance, the relevance of the maintenance management has been proven in several books ([47], [48], [49] and [50])). Indeed, a good maintenance management can help the company to remain competitive both nationally and internationally.

According to our bibliographic review, a properly implemented maintenance management has a positive impact not only on the infrastructure, the resources (human and material) and the company management (spare parts, inventory, etc.) but also on the environment (see [6], [51],[52], [53], [32], [55]). The maintenance allows then to ensure the people safety and to limit the negative impacts of a material on the environment. Indeed, efficient maintenance interventions will:

- Extend the lifetime of assets

- Secure people and the properties

- Reduce noise (e.g. vibration of engines).

- Reduce consumption of matter and energy (e.g. water and electricity)

- Reduce solid and liquid waste (oil leakage...)

- Reduce air pollution (gas leakage...)

- Reduce environmental costs (the penalties cost due to the impact of the production system deterioration on the environment).

Thus, we can deduce that maintenance contributes to the environmental performance by reducing the environmental impacts. This positive impact of maintenance on the environment can be translated into an improvement of the environmental performance indicators. 


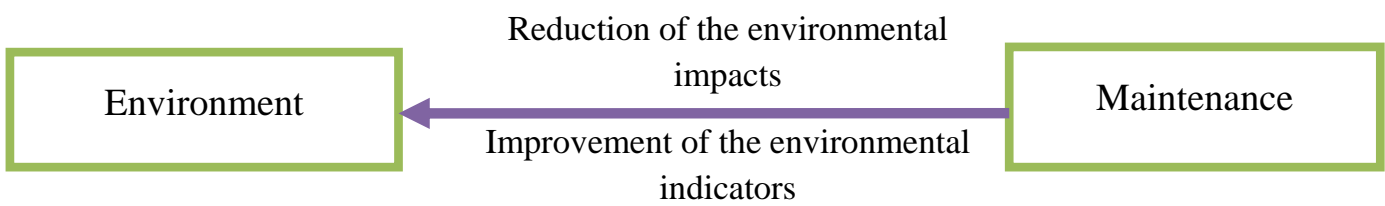

Fig.1. The « maintenance - environment » relationship

If maintenance management contributes to the environmental performance, the integration of the maintenance function into the design and functioning of an EMS is then essential. This supports the consideration of maintenance as a requirement in ISO 14001 standard. We quote this sentence of paragraph 4.4.1 entitled Resources, Roles, Responsibility and Authority: "Management must ensure the availability of the essential resources for the establishment, Implementation, keeping up-to-date and the improvement of the environmental management system. These resources include human resources, specific skills, organizational infrastructure, technological and financial resources".

Responding to this requirement implies a specific organization of the maintenance function. This organization would result in an organizational performance at the maintenance function level.

In addition, environmental management requires defining, for each process that includes the maintenance process, the environmental aspects and their impacts. The company is obliged, in this sense, to propose actions and procedures to control these aspects and limit their impacts on the environment. These actions and procedures will introduce a new management approach in the maintenance department.

We can thus deduce that the environmental management requires a certain maintenance organization which, in turn, has a positive impact on maintenance performance indicators.

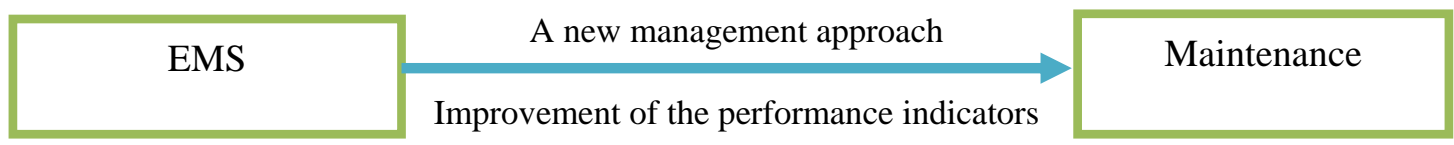

Fig.2. The « environment - maintenance » relationship

The aggregation of relations (1) and (2) gives the global model explaining both directions of the relation "environment - maintenance".

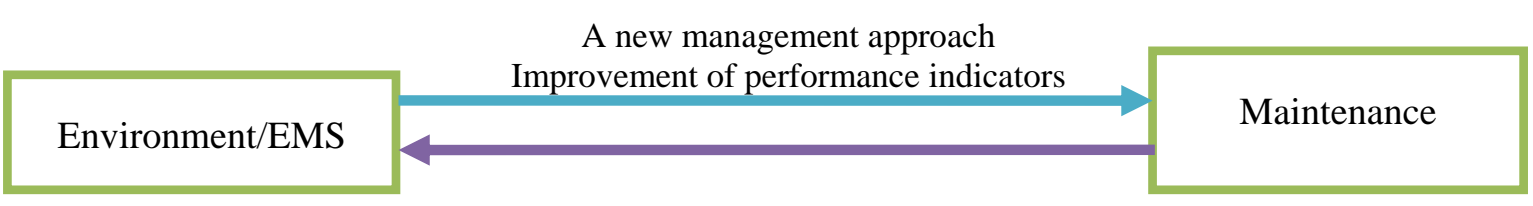

Reduction of the environmental aspects

Improvement of environmental indicators

Fig.3. The whole « maintenance - environment » relationship

\section{Experimentation of the model in the Moroccan context}

\section{A. Presentation of the BOISGAZ Company}

The company BOISGAZ is a national leader in agri-food soft drinks. It bottles and markets 14 brands with its various perfumes, which totals 104 references. The manufacturing process within BOISGAZ goes through several stages:

Firstly, water treatment that aims to eliminate the colloidal substances and suspended solids, to eliminate any coloration, odor and any undesirable taste and decrease the alkalinity. Then, the manufacturing of two kinds of syrups: simple syrup and finished syrup. In the end, the phase of bottling in two types of bottles: glass and PET bottles.

The BOISGAZ Company, certified 14001 since 2005, presents various aspects to the environment and has a Wastewater Treatment Plant (WWTP) located next to its production site. The station ensures the treatment of the waste water of BOISGAZ before pouring them into the sewer system of the city in order to meet the standards required by the parent company and the Moroccan norms of indirect rejections. 
At the entry of the WWTP the $\mathrm{pH}$ is basic because the effluents of the water at the inlet are rich by the soda used for the cleaning of the bottles. The water temperature and the BOD5, COD5 and ME concentrations exceed the values determined by the Moroccan indirect discharges standard and by BOISGAZ itself.

\section{B. The BOISGAZ environmental indicators}

BOISGAZ environmental indicators are grouped into classes and calculated as following:

- $\quad$ Energy ratio (electricity, fuel, soda).

- Yield of raw materials (concentrate, water, sugar, CO2).

- Yield of packaging material (plug, capsule, and label).

- Waste ratio: the amount of waste in Kg/production of final product in (l).

- WWTP yield: the amount of incoming water untreated/the amount of the outgoing treated water.

The objectives are established and required by the parent company, they are usually the best values reached by different sites.

\section{Analysis of the maintenance organization of BOISGAZ}

The maintenance department at BOISGAZ takes care of all the equipment of the company and aims to ensure the availability and the good functioning of the equipment especially those used for the production. To do this, the company ensures the maintenance of the equipment according to specified terms of preventive and corrective maintenance, if necessary, through requests for intervention.

The performance of the maintenance department is measured by the following performance indicators:

- $\quad$ Preventive maintenance rate.

- Availability.

- $\quad$ Respect for the maintenance budget.

- Number of WA (Work Accident).

D. Experimentation of the relationship « environment - maintenance »

1) The impact of maintenance management on the environmental management

In order to measure the impact of maintenance on the environment, we started by analyzing the dashboard (or reporting) environment. This dashboard consists of a set of indicators grouped into three families: 'raw materials', 'energy' and 'packaging material'.

Within each family, a set of indicators is defined, calculated and then compared with the goal of the concerned year (see table I).

The calculation of these indicators for the year 2014 showed several negative gaps. These gaps concern the maintenance department and require an action plan (see table II).

TABLE I. Reporting extract for the year 2014

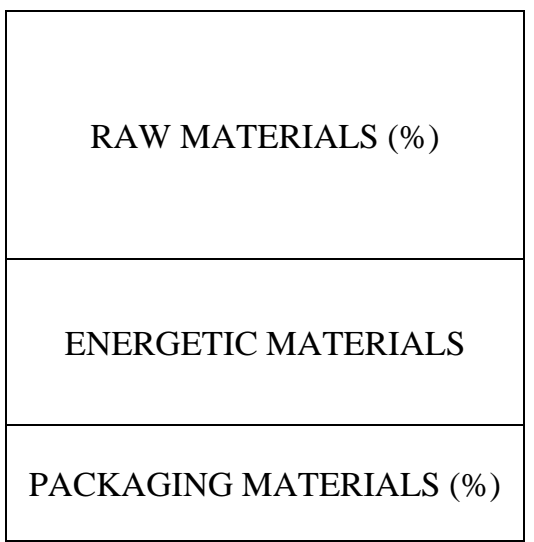

\begin{tabular}{|l|}
\hline CONCENTRATE \\
SUGRE \\
CO2 \\
WATER (L/LFP) \\
\hline ELECTRICITY (LFP/KWh) \\
FUEL (LPF/KG) \\
SODA (GR/LFP) \\
\hline PLUG\& CAPSULES \\
LABELS \\
\hline
\end{tabular}

\begin{tabular}{|c|}
\hline GAP14Vsobj \\
\hline$-0,04$ \\
$-0,08$ \\
$-0,59$ \\
0,25 \\
\hline$-1,29$ \\
$-18,88$ \\
$-0,3$ \\
\hline$-0,05$ \\
0,04 \\
\hline
\end{tabular}


TABLE II. An extract of the maintenance action plan for the year 2014

\begin{tabular}{|c|c|c|c|c|c|c|}
\hline \multicolumn{2}{|c|}{ Monitoring indicator } & \multirow{4}{*}{$\begin{array}{c}\begin{array}{c}\text { Gap } \\
\text { Ytd/object }\end{array} \\
-0,04 \\
-0,08\end{array}$} & \multirow{2}{*}{\begin{tabular}{l}
\multicolumn{1}{c}{ Cause analysis } \\
Ambient temperature of \\
the room is high
\end{tabular}} & \multirow{2}{*}{$\begin{array}{c}\text { Action } \\
\text { Air conditioning (cooling) of the syrup room }\end{array}$} & \multirow{2}{*}{\begin{tabular}{c|c} 
Resp \\
\\
$\mathrm{RP} / \mathrm{RM}$ \\
\end{tabular}} & \multirow{2}{*}{\begin{tabular}{|r|} 
Status \\
Planned
\end{tabular}} \\
\hline \multirow{5}{*}{ 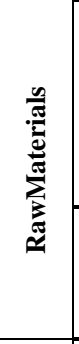 } & \multirow{3}{*}{$\begin{array}{l}\text { Concentrated } \\
\text { yield and } \\
\text { sugar }\end{array}$} & & & & & \\
\hline & & & $\begin{array}{l}\text { Syrup temperature is } \\
\text { high. }\end{array}$ & Establishment of a new interchange & $\mathrm{RM}$ & Planned \\
\hline & & & Price fluctuations & Control of pipes, flowmeters and valves & RM & Planned \\
\hline & \multirow{2}{*}{$\mathrm{CO} 2$} & \multirow{2}{*}{$-0,59$} & \multirow{2}{*}{ CO2 Yield Analysis } & $\begin{array}{l}\text { Installation of the deaeration valve V2, Change of liquid air } \\
\text { regulator }\end{array}$ & \multirow{2}{*}{$\mathrm{RM}$} & \multirow{2}{*}{ Planned } \\
\hline & & & & CO2 system checking: Mixer and filler (leak and pressure) & & \\
\hline \multirow{13}{*}{ 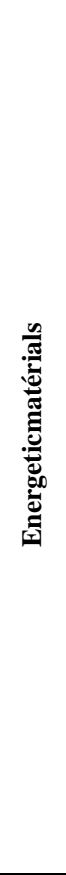 } & \multirow{6}{*}{$\begin{array}{l}\text { Fuel } \\
\text { yield }\end{array}$} & \multirow{6}{*}{$-18,88$} & Low boiler yield & Boiler yield analysis & $\mathrm{RM}$ & Planned \\
\hline & & & \multirow{5}{*}{ Low boiler yield } & Measure smoke temperature & \multirow{5}{*}{$\mathrm{RM}$} & \\
\hline & & & & Analysis of the combustion, sweeping of the boiler $\mathrm{N}^{\circ} 3$ & & \\
\hline & & & & Check the trigger input V1 washer and carbon filter & & \\
\hline & & & & Ant tartar treatment and trap control & & \\
\hline & & & & $\begin{array}{l}\text { Installing a pression regulator at the inlet of V2 washer and } \\
\text { charcoal filters }\end{array}$ & & \\
\hline & \multirow{5}{*}{ Electricity } & \multirow{5}{*}{$-1,29$} & $\begin{array}{l}\text { Clogging of the } \\
\text { exchangers LV1/LV2. }\end{array}$ & Changing joints of the exchangers LV1/LV2. & $\mathrm{RM}$ & Planned \\
\hline & & & $\begin{array}{l}\text { Clogging of the } \\
\text { exchangers NH3/Glycol. }\end{array}$ & Monitoring of cold exchanger & RM & Demandoffer \\
\hline & & & $\begin{array}{l}\text { Clloging of the syrup } \\
\text { room exchangers }\end{array}$ & Contimol exchanger monitoring and change of SS cooling & $\mathrm{RM} / \mathrm{RP}$ & Planned \\
\hline & & & Air leakage & Elimination of air leakage & RM & Planned \\
\hline & & & $\begin{array}{l}\text { Analysis of energy } \\
\text { consumption }\end{array}$ & $\begin{array}{l}\text { Automation of conveyors glass lines, raise awareness among } \\
\text { drivers on the shutdown of conveyors in case of stopping } \\
\text { production }\end{array}$ & $\mathrm{RM}$ & Planned \\
\hline & \multirow{2}{*}{ Soda } & \multirow{2}{*}{$-0,3$} & \multirow{2}{*}{$\begin{array}{l}\text { High consumption of } \\
\text { Soda }\end{array}$} & $\begin{array}{l}\text { Reduce the number of drain washer by a better extraction of } \\
\text { labels }\end{array}$ & $\mathrm{RM}$ & Planned \\
\hline & & & & $\begin{array}{l}\text { Monitoring of the consumption of soda (leaks, washers), control } \\
\text { of soda consumption }\end{array}$ & $\mathrm{RM} / \mathrm{RP}$ & Planned \\
\hline \multirow{3}{*}{ 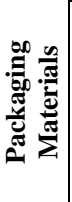 } & \multirow{3}{*}{ Crown cap } & \multirow{3}{*}{$-0,05$} & \multirow{3}{*}{ Cap yield analysis } & $\begin{array}{l}\text { Systematize the count of receipts having a decline in } \\
\text { performance }\end{array}$ & $\mathrm{RM}$ & Planned \\
\hline & & & & Revision of the defective capper head & $\mathrm{RM}$ & Planned \\
\hline & & & & $\begin{array}{l}\text { Check the filler gear V2 and the stars of entry to lower the rate } \\
\text { of unfilled bottle }\end{array}$ & $\mathrm{RM}$ & Planned \\
\hline
\end{tabular}

Implementation of the Action Plan improved for 2015 all the indicators that were problematic for the year 2014. Thus, by 2015, the comparison of environmental performance with the Objective 2015 (the same target for 2014) shows an improvement in environmental performance as indicated in table III below:

TABLE III. The summary reporting for the year 2015 and the year 2014

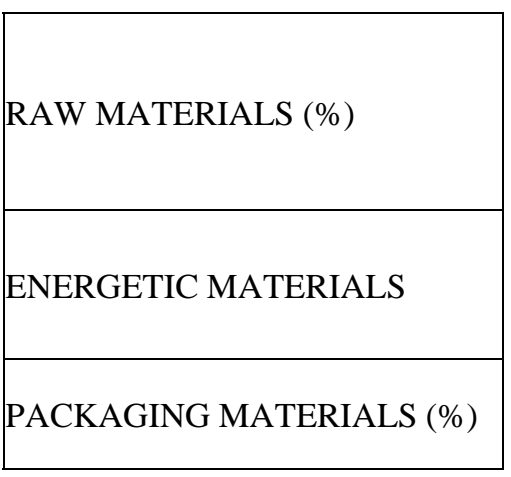

\begin{tabular}{|l|}
\hline CONCENTRATE \\
SUGRE \\
CO2 \\
WATER (L/LPF) \\
\hline ELECTRICITY (LPF/KWh) \\
FUEL (LPF/KG) \\
SODA (GR/LPF) \\
\hline PLUGS\& CAPSULES \\
LABELS \\
\hline
\end{tabular}

\begin{tabular}{|c|}
\hline GAP 14Vsobj \\
\hline$-0,04$ \\
$-0,08$ \\
$-0,59$ \\
0,25 \\
\hline$-1,29$ \\
$-18,88$ \\
$-0,3$ \\
\hline$-0,05$ \\
0,04 \\
\hline
\end{tabular}

\begin{tabular}{|c|}
\hline GAP 15Vs Ob \\
\hline 0,11 \\
0,15 \\
0,92 \\
$-0,29$ \\
\hline 0,34 \\
$-6,52$ \\
$-0,14$ \\
\hline 0,00 \\
0,04 \\
\hline
\end{tabular}


As a result, maintenance actions have improved for the year 2015 environmental performance. This confirms our assumption that an improvement of the maintenance improves environmental performance.

At the level of the WWTP, the availability is essential to limit liquid discharges into the environment. However, we found that the station suffered several failures with long shutdown times that can reach up 3 days (see fig.4).

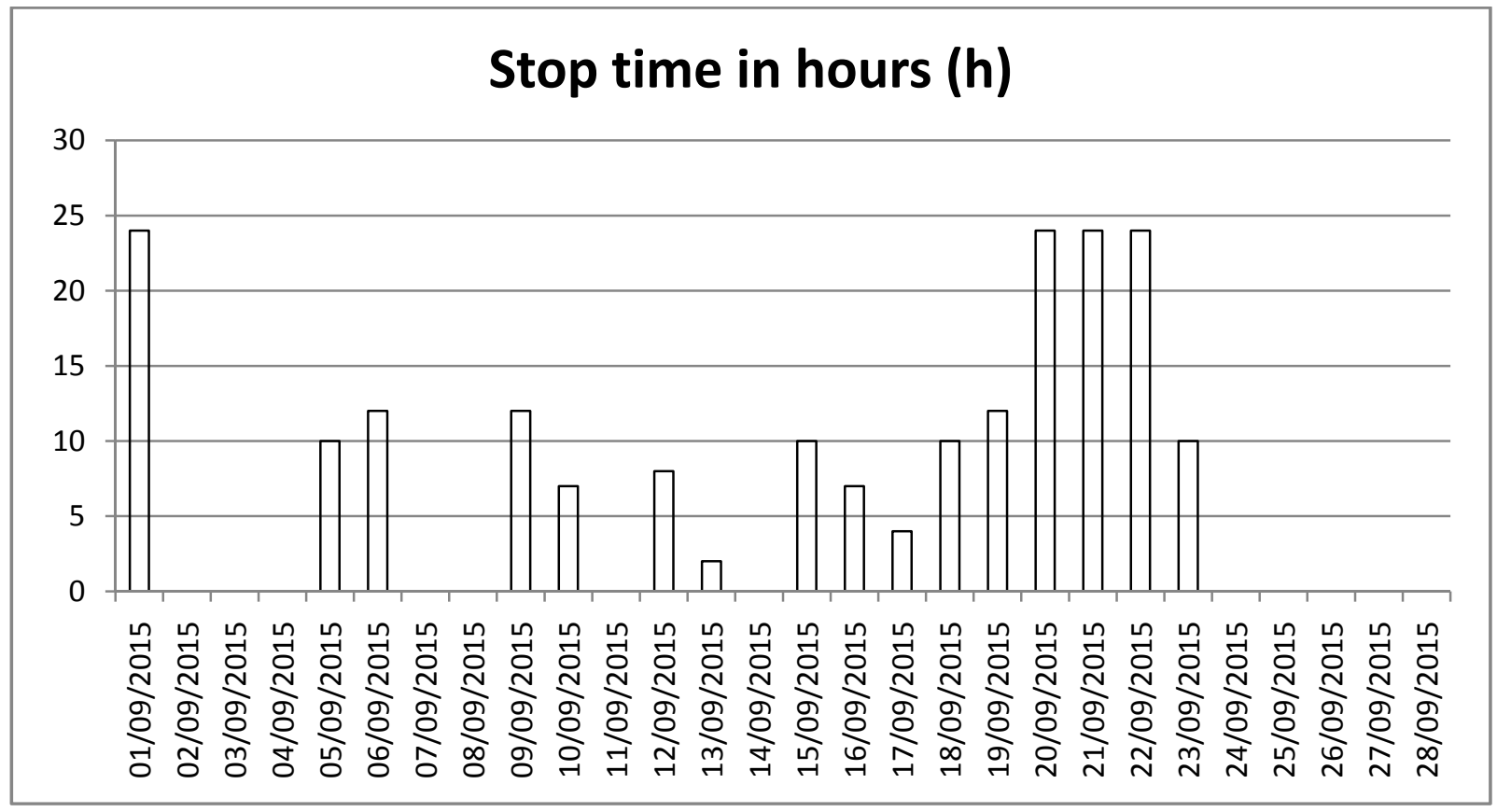

Fig.4: Stop time on September 2015 (According to the alarm menu).

The reduction of these failures requires a maintenance action. However, we noticed a lack of interest in the station. Indeed, maintenance of the WWTP is not a priority for the maintenance department and this is due to the fact that the environmental law is not yet in force. On the other hand, indicators of performance related to the WWTP calculate different yields but this calculation does not take into account the availability of the WWTP (the performance is calculated when the WWTP is running).

Thus, a lack of maintenance at the WWTP level leads to environmental degradation (see, for example, Table IV relating to the values of environmental indicators at the entry of the WWTP).

TABLE IV. The values of the environmental indicators at the entry of the WWTP

Month 04/2014

\begin{tabular}{|l|l|l|l|l|l|l|l|}
\hline Parameters & $\mathbf{T}\left({ }^{\circ} \mathbf{C}\right)$ & pH & COD (mg/l) & DBO 5 (mg/l) & MES (mg/l) & N t (mg/l) & P t (mg/l) \\
\hline E & 27 & 10,2 & 2513,1 & 595 & 281,6 & 9,31 & 1,51 \\
\hline
\end{tabular}

Indeed, the PH as well as the different concentrations of BOD5, COD and MES far exceeds the values required by the regulations (see table $\mathrm{V}$ on Regulation).

TABLE V. Moroccan Standards for indirect discharges of BOISGAZ

\begin{tabular}{|l|l|l|l|l|l|l|l|}
\hline Industry & $\mathbf{Q m o y}(\mathbf{m} 3 / \mathbf{j})$ & $\mathbf{Q m a x}(\mathbf{m} 3 / \mathbf{j})$ & $\mathbf{p H}$ & $\mathbf{T}\left({ }^{\circ} \mathbf{C}\right)$ & $\mathbf{D B O 5}(\mathbf{m g} / \mathbf{l})$ & $\mathbf{C O D}(\mathbf{m g} / \mathbf{l})$ & $\mathbf{M E S}(\mathbf{m g} / \mathbf{l})$ \\
\hline BOISGAZ & 250 & 750 & $6---9$ & 35 & 500 & 1000 & 600 \\
\hline
\end{tabular}

This confirms our hypothesis that a lack of maintenance leads to environmental degradation.

2) The impact of environmental management on maintenance management

In order to measure the impact of environmental management on maintenance at BOISGAZ, we analyzed the company's EMS especially how the company met the requirements of paragraph 4.4.1, which deals among many things with the maintenance requirements. This analysis showed that, during the design and implementation of the EMS, a particular maintenance organization was required to provide more preventive maintenance than corrective maintenance. This organization was reflected in the new performance indicators:

- $\quad$ Preventive maintenance rate $=$ duration preventive intervention / total intervention period

- $\quad$ Preventive /correctif report $=95 / 5$ 
It should be noted that these two indicators (imposed by QSE department) have a positive impact on the availability (maintenance performance indicator) calculated by the maintenance department of BOISGAZ according to the following formula:

- $\quad$ Availability = MTBF / $(\mathrm{MTBF}+\mathrm{MTTR})$

The Table VI summarizes the different maintenance indicators for the year 2015.

TABLE VI. Review of the maintenance indicators calculation for 2015

\begin{tabular}{|c|c|c|c|c|c|c|c|c|c|c|c|c|c|}
\hline Maintenance & & \multicolumn{12}{|c|}{ Achievements } \\
\hline $\begin{array}{l}\text { Performance } \\
\text { Indicators }\end{array}$ & Objectives & Jan & Febv & Mar & Apr & May & June & Jul & Aou & Sep & Oct & Nov & Dec \\
\hline $\begin{array}{l}\text { Rates of } \\
\text { preventive } \\
\text { maintenance }\end{array}$ & Sup $95 \%$ & 94.45 & 98.5 & 94.97 & 96.96 & 95.5 & 98.9 & 99.6 & 93.77 & 97.6 & 98.7 & 95 & \\
\hline $\begin{array}{l}\text { Rate of } \\
\text { corrective } \\
\text { maintenance }\end{array}$ & Inf $5 \%$ & 5.5 & 1.5 & 5 & 3 & 4.5 & 1.1 & 0.4 & 6.2 & 2.4 & 1.7 & 5.1 & \\
\hline $\begin{array}{l}\text { Rate of ligne } \\
\text { availability }\end{array}$ & $97,5 \%$ & 94 & 98 & 96 & 98 & 97 & 98 & 99 & 82 & 98 & 99 & 95 & \\
\hline
\end{tabular}

On the other hand, environmental management requires identification for all processes of the company, including the maintenance process, the environmental aspects and impacts. Analysis of different environmental aspects shows that there are aspects related to maintenance (normal functioning mode of the maintenance department). Other aspects related to production appear in an abnormal functioning of the production because of a stop or a degradation of the material.

Thus, management of these aspects and control of their impacts requires specific actions within the maintenance department. These actions will reduce the significance of the aspects.

We present in the following table (table VII), an extract of our analysis on the environmental aspects.

TABLE VII. An extract from an analysis on significant environmental aspects

\begin{tabular}{|c|c|c|c|c|c|}
\hline \multicolumn{2}{|r|}{ Activity } & Aspect & Field & Impact & $\mathbf{S}$ \\
\hline \multirow{3}{*}{ 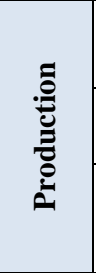 } & Bottling & $\begin{array}{l}\text { Rejection of the final } \\
\text { product }\end{array}$ & Water & Pollution DBO/DCO & 24 \\
\hline & Coding & $\begin{array}{l}\text { Leakage of solvent } \\
\text { and inks }\end{array}$ & Water & $\begin{array}{l}\text { Contamination of groundwater by } \\
\text { infiltration }\end{array}$ & 24 \\
\hline & $\begin{array}{c}\text { Washing \& Inspection of } \\
\text { Bottles }\end{array}$ & $\begin{array}{l}\text { Hot water discharge / } \\
\text { chemical products }\end{array}$ & Water & $\begin{array}{l}* \text { Temperature rise, Sewer system } \\
\text { degradation, degradation of fauna } \\
\text { and flora }\end{array}$ & 27 \\
\hline ڤ & $\begin{array}{l}\text { Sanitation equipment, } \\
\text { cleaning and } \\
\text { maintenance }\end{array}$ & $\begin{array}{l}\text { Discharges of caustic } \\
\text { soda of disinfectants } \\
\text { and hot water }\end{array}$ & Water & $\begin{array}{l}* \text { Groundwater contamination / } \\
\text { Fauna and flora } \\
* \text { Degradation of the sewerage } \\
\text { network }\end{array}$ & 36 \\
\hline \multirow{2}{*}{ 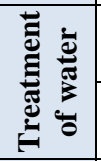 } & $\begin{array}{l}\text { Coagulation / } \\
\text { disinfection }\end{array}$ & $\begin{array}{l}\text { Coagulant and } \\
\text { chlorine leak }\end{array}$ & Water & $\begin{array}{l}\text { Contamination of groundwater by } \\
\text { infiltration }\end{array}$ & 36 \\
\hline & Regeneration of resins & $\begin{array}{l}\text { Rejection of } \\
\text { Chemicals (HCl) }\end{array}$ & Water & Contamination of groundwater & 32 \\
\hline \multirow{2}{*}{ ฮี } & \multirow{2}{*}{ Resourcesconsumption } & Water Consumption & Resource & Resource depletion & 48 \\
\hline & & $\begin{array}{l}\text { Electricity } \\
\text { consumption }\end{array}$ & Resources & Resource depletion & 48 \\
\hline \multirow{3}{*}{ 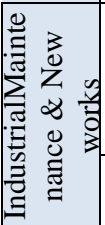 } & \multirow{2}{*}{$\begin{array}{l}\text { Assembly, disassembly } \\
\text { and adjustment }\end{array}$} & $\begin{array}{l}\text { Rejection of soiled } \\
\text { cloths }\end{array}$ & Soil & $\begin{array}{l}\text { Landscape degradation, soil } \\
\text { contamination by infiltration }\end{array}$ & 32 \\
\hline & & $\begin{array}{l}\text { Discharges of waste } \\
\text { oils }\end{array}$ & $\begin{array}{c}\text { Soil / } \\
\text { Water }\end{array}$ & $\begin{array}{l}\text { Contamination of groundwater by } \\
\text { infiltration, landscape degradation }\end{array}$ & 27 \\
\hline & Welding \& cutting & Solid waste disposal & Soil & landscape degradation & 16 \\
\hline
\end{tabular}

F: Frequency of the operation / Aspect

G: Impact of severity on the receiving environment
P: Probability of environmental incident $\mathrm{S}^{*}$ : Significance of the aspect 
The significance is equal to the product of the frequency, probability and severity:

$$
\mathrm{S}=\mathrm{P} * \mathrm{~F}^{*} \mathrm{G}
$$

One aspect is considered to be significant when:

- $\quad$ There is a regulatory or a requirement of ISO 14001.

- $\quad$ The product of the frequency * probability * gravity exceeds 24 .

- Severity is 4.

An action plan was developed to reduce the significance of the impacts. Numerous actions concern the maintenance department such as development and management procedures (for exp: procedures for management of liquid and solid waste and procedures on emergency procedures), as well as training/awareness.

Mastering these aspects and their impacts requires a high availability of the material. To achieve this, maintenance department (with a recommendation of the QSE) plans a special organization through the development of a set of procedures and adoption of preventive maintenance (a rate of $95 \%$ ).

\section{Conclusion}

If the negative impact of a production system on the environment and the impact of maintenance management on the production system seem obvious, the direct impacts between maintenance and the environment are not always evident. Our research fits into this framework and shows that maintenance management impacts environmental performance, so good environmental management within an industry influences the management of maintenance. At the end of this research we elaborated a model on the relation 'environment -maintenance'.

The results obtained from the 'BOISGAZ' company confirm the relationship between the management of maintenance and the improvement of environmental performance and also a relationship between environmental management and the improvement of the maintenance management. These results were also confirmed through a qualitative study with seven Moroccan SMEs.

\section{REFERENCES}

[1] Terrier, 2002, La maintenance, DESS Quassi, département qualité.

[2] Monchy F, Pichot C, 2003, Maintenance Méthodes et organisations, Dunod, Usine Nouvelle, Paris

[3] Souris JP, 1993, La maintenance source de profit, Editions d'organisation, Paris.

[4] Retour D., Bouche M. et Plauchu V., Où va la maintenance industrielle, Problème économiques No 2159,pp7-13,janvier 1990.

[5] Francastel J.C, 2005, Externalisation de la maintenance stratégie - méthodes - contrats, 2ème édition, Dunod,Paris

[6] Chouikhi H., Optimisation des stratégies de maintenance verte pour les systèmes de production de biens et de services, thèse, École doctorale IAEM Lorraine, UFR Mathématiques, Informatique, Mécanique - Metz, 2012

[7] Nash J. et Ehrenfeld J., Factors that shape EMS outcomes in firms, 2001, p.62.

[8] Desmazes J. et Lafontaine J-P., L'assimilation des budgets environnementaux et du tableau de bord vert par les entreprises, 28e Congrès de l'association francophone de comptabilité, Poitiers, 2007.

[9] Riedinger N. et Thévenot C., La norme ISO 14001 est-elle efficace? Une étude économétrique sur l'industrie française, Economie et statistique $n^{\circ} 411,2008$.

[10] Boiral O., Le système de management environnemental comme moyen de contrôle de la déclinaison et de l'émergence des stratégies environnementales, Université de Poitiers, Thèse de doctorat en sciences de gestion, soutenue en novembre 2009.

[11] Reverdy T., Les normes environnementales en entreprise : la trajectoire mouvementée d'une mode managériale, Sociologies Pratiques, $\mathrm{n}^{\circ} 10,2005$

[12] Bouquin H. (1986), Le contrôle de gestion, Presses Universitaires de France, Paris.

[13] Bescos P., Dobler P., Mendoza C., Naulleau G. (1993), Contrôle de gestion et management, Montchrestien, $2^{\circ}$ édition.

[14] Bourguignon A. (1995), « Peut-on définir la performance ? », Revue Française de Comptabilité, juilletaoût, pp.61-66.

[15] Lebas M. (1995), « Oui, il faut définir la performance », Revue Française de Comptabilité, juillet- août, pp.66-71.

[16] Bessire D. (1999), « Définir la performance », Comptabilité Contrôle Audit, septembre, pp.127-150.

[17] Janicot L. (2007), "Les systèmes d'indicateurs de performance (IPE), entre communication et contrôle », Comptabilité Contrôle Audit, tome 13, vol. 1, pp.47-68.

[18] Gendron C. (2004), La gestion environnementale et la norme ISO 14001, Les Presses Universitaires de Montréal, Montréal.

[19] Dias-Sardinha I., Reijnders L. et Antunes P. - From Environmental Performance Evaluation to EcoEfficiency and Sustainability Balanced Scorecards - Environmental Quality Management - Vol. 12 - Issue 2 - 2002 - p 51- 64, 14 pages

[20] Bouquin H. (2004), Le contrôle de gestion, Presses Universitaires de France, Collection Gestion, Gème édition, Paris, 508 p.

[21] Arts, R. H. P. M., Knapp, G.M., Mann, L. (1998). "Some Aspects of Measuring Maintenance Performance in Process Industry." Journal of Quality in Maintenance Engineering 4(1): pp6-11.

[22] Tsang, A. H. C. (1999). "Measuring Maintenance Performance: A holistic Approach." International Journal of Operations and Production management Vol.19(No.7): pp 691- 715.

[23] Visser, J. K., Pretorious M.W., (2003). "The Development of a Performance Measurement System for Maintenance." SA Journal of Industrial Engineering 14(1): pp83-97.

[24] Weber, A., Thomas, R., (2006). Key Performance Indicators: Measuring \& Managing the Maintenance Function. Ivara Corporation.

[25] Parida, A., Chattopadhyay, G. (2007). "Development of a multi-criteria hierarchical framework for maintenance performance measurement (MPM)." Journal of Quality in Maintenance Engineering. vo vol.13(3): pp241-258.

[26] Parida, A. and Kumar, U. (2006), "Maintenance performance measurement (MPM): issues and challenges", Journal of Quality in Maintenance Engineering, Vol. 12 No. 3, pp.

[27] Cross, Michael (1988a). "Engineering maintenance Organization Performance an Assessment of the Evidence from over 200 sites", Management Research News, Vol. 11 No. 1/2, pp. 20-23.

[28] Komonen, Kari (2002), “A cost model of industrial maintenance for profitability analysis and benchmarking”, International Journal of Production Economics, Vol. 79, pp. 15-31. 
[29] Raouf, Abdul (1993), “On Evaluating Maintenance Performance”, International Journal of Quality \& Reliability Management, Vol. 10 No. 3, pp. 33-36.

[30] Eti, M. C., Ogaji, S. O. T. and Probert, S. D. (2005), "Maintenance schemes and their implementation for the Afam Thermal-Power station”, Applied Energy, Vol. 82, pp. 255-265.

[31] De Groote, P. (1995), "Maintenance performance analysis: a practical approach” Journal of Quality in Maintenance Engineering, Vol. 1 No. 2, pp. 4-24.

[32] C. PELLEGRIN « Fondement de la décision maintenance » Editions Economica - 1997

[33] F. MONCHY «La fonction maintenance, formation à la gestion de la maintenance industrielle » Editions Masson - Paris - 1996

[34] F. BOUCLY « Le management de la maintenance évolution et mutation » Editions AFNOR - 1998

[35] C.GORMAND « Le coût global (life cycle cost) pour investir plus rationnellement » Editions AFNOR - 1986

[36] S. NAKIJIMA « La maintenance Productive Totale (TPM) » Editions AFNOR gestion Paris 1989

[37] F.Pérès, et al, la maintenance dans l'évaluation des performances des systèmes de production : une approche par simulation, laboratoire de Génie de Production

[38] P.Vrignat et all, Génération d'indicateurs de maintenance par une approche semi paramétrique et par une approche markovienne, hal00684468, 2012

[39] L.BERRAH. L'indicateur de performance : concepts et applications. Editions Cépaduès. 2002.

[40] LARATTE B., thèse de doctorat, Evaluation dynamique et cumulative des impacts environnementaux dans le cadre d'une analyse de cycle de vie, l'UNIVERSITE DE TECHNOLOGIE DE TROYES, 2013.

[41] Boufateh Ben ArariI., thèse de doctorat, contribution à l'évaluation de la supply Chain pour la filière textile : définition de critère de développement durable, Ecole Nationale Supérieur des Arts et Industries Textiles, France, 2011.

[42] M-A.Méquignon, Comment la durée de vie des bâtiments peut-elle influencer les performances en termes de développement soutenable?, thèse de doctorat, L'Institut National des Sciences Appliquées de Toulouse, 2011

[43] TÄHKÄMÖ L., Life cycle assessment of light sources - Case studies and review of the analyses, thèse de doctorat, Université de Toulouse III - Paul Sabatier, 2013.

[44] Ben Ayed R., Eco-conception d'une chaine de traction ferroviaire, thèse de doctorat, L'ECOLE CENTRALE DE LILLE, 2012

[45] BOURREAUL., thèse de doctorat, Contribution de la dimension conformité règlementaire à la mesure de la performance des systèmes de management environnemental : Proposition d'un outil de mesure, l’École nationale supérieure des mines de Paris, 2012.

[46] Melbouci L., L'ENTREPRISE ALGÉRIENNE FACE À QUEL GENRE D'ENVIRONNEMENT ?, La Revue des Sciences de Gestion, Direction et Gestion n 234 - Stratégie, 2008.

[47] Monchy, F, La fonction maintenance: Formation à la gestion de la maintenance industrielle, Collection technologies de l'université de l'industrie, MASSON, 1991

[48] Lyonnais P., Maintenance mathématique et méthode, troisième édition, technique et édition Lavoisier, France, 1992

[49] Pricket P.W., An integrated aproach to autonomous maintenance management , Integrated Manufacturing Systems, Vol. 10. No. 4, pp. 233-243, 1999

[50] Jardine A. K. S., Joseph T. et Banjevic D., Optimizing condition-based maintenance decision for equipment subject to vibration monitoring, Journal of Quality in Maintenance Engineering, Vol. 5, No. 3, pp. 192-202, 1999

[51] Zille. V Modélisation et évaluation des stratégies de maintenance complexes sur des systèmes multi-composants, thèse de doctorat, l'Université de Technologie de Troyes, Institut Charles Delaunay, 2009.

[52] DeSimone, L.D., F. Popoff and the World Business Council for Sustainable Development (WBCSD). Eco-efficiency. MIT Press, Cambridge, Massachusetts, United States of America, 306 pages, 1997.

[53] El Aoufir H., contribution à la gestion des coûts de maintenance et l'aide à la décision des stratégies de maintenance, thèse de doctorat, l’École Mohammadia des Ingénieurs (EMI), 2003

[54] C. PELLEGRIN « Fondement de la décision maintenance » Editions Economica - 1997

[55] Tajri H. et al., INTEGRATION OF THE ENVIRONMENTAL DIMENSION IN MAINTENANCE DECISION SUPPORT TOOL FMEA: CASE OF A MOROCCAN FOUNDRY,Global Journal of Engineering Science and Research Management, 2(10): October, 2015 